\title{
Physiology of sulfide detoxification in the isopod Saduria (Mesidotea) entomon
}

\author{
Bent Vismann \\ Marine Biological Laboratory, University of Copenhagen, Strandpromenaden 5, DK-3000 Helsingor, Denmark
}

\begin{abstract}
The physiology of sulfide detoxification in the isopod Saduria (Mesidotea) entomon (L.) was studied in vitro as well as in vivo using a sulfide oxidation assay and high-performance liquid chromatography. S. entomon is unable to prevent hydrogen sulfide from entering its body. Hydrogen sulfide is transported by the blood to the hepatopancreas, where it is detoxified in the fluid portion by an $\mathrm{O}_{2}$-dependent oxidation to $\mathrm{S}_{2} \mathrm{O}_{3}{ }^{2-}$ and $\mathrm{SO}_{3}{ }^{2-}\left(\mathrm{S}^{0}\right.$ or $\mathrm{SO}_{4}{ }^{2-}$ formation could not be demonstrated). An $\mathrm{O}_{2}$ independent binding of sulfide, probably by iron, also occurs in the hepatopancreas. In addition, $\mathrm{H}_{2} \mathrm{~S}$ is oxidized to $\mathrm{S}_{2} \mathrm{O}_{3}{ }^{2-}$ in the muscle. This oxidation is suggested to be localized in the mitochondrial fraction of the muscle. Glutathione does not play an important role in the detoxification. This study supports the hypothesis that hydrogen sulfide is an important factor in the distribution of marine invertebrates in soft sediments.
\end{abstract}

\section{INTRODUCTION}

Hydrogen sulfide is known to be toxic to aerobic organisms at nanomolar to micromolar concentrations (National Research Council 1979). This toxicity is caused by inhibition of metalloenzymes, and especially cytochrome oxidase and blood pigments (Evans 1967). Nevertheless, hydrogen sulfide is produced internally as a by-product in the degradation of sulfur-containing proteins, certain coenzymes and metabolites. Sulfide is also produced by microbial fermentation in the alimentary canal (Siegel 1975). Detoxification mechanisms are necessary in order to avoid the toxic effects of this internally produced sulfide. Sulfide oxidation has been demonstrated in the liver and kidney of rats (Baxter et al. 1958, Sörbo 1958). Exposed to sulfide, dogs and rats excrete sulfate in the urine (Dziewiatkowski 1945, Yokoyama et al. 1971, Curtis et al. 1972). Sulfide is also oxidized by the blood plasma of vertebrates (Haggard 1921, Evans 1967).

Marine sediments are typically anoxic a few $\mathrm{mm}$ or $\mathrm{cm}$ beneath the surface and contain up to millimolar concentrations of sulfide (Fenchel \& Riedl 1970). Sulfide is produced principally by sulfate-respiring bacteria and to a lesser extent by the fermentative degradation of proteins (Fenchel 1969). Thus, sedimentdwelling invertebrates face the risk of exposure to hydrogen sulfide in the environment.

Some invertebrates cope with the sulfide by irriga- tion with water from above the sediment so that their surroundings remain oxidized (e.g. Meyers et al. 1987 , 1988). In sulfide-rich sediments this is not always effective, viz. at low tide or when sulfide is present in the bottom water or when the animals establish new tubes or move within the sediment. Invertebrates from sulfide-rich environments are therefore likely to show an increased tolerance to hydrogen sulfide. Differential tolerance to sulfide may influence the distribution of marine infaunal invertebrates.

Studies indicating that hydrogen sulfide is an important environmental factor in the distribution of animals are accumulating. Thus a high tolerance to hydrogen sulfide in fauna from sulfide-rich environments has been shown by e.g. Jacubowa \& Malm (1931), Theede et al. (1969), Oertzen \& Schlungbaum (1972), Degn \& Kristensen (1981), Oeschger \& Schmaljohann (1988), Bagarinao \& Vetter (1989), Oeschger \& Storey (1990), and Vismann (1990). Sulfide catalysis has been demonstrated in a number of sediment-dwelling species (Patel \& Spencer 1963, Powell et al. 1979, Powell \& Somero 1985, 1986, Anderson et al. 1987, Vetter et al. 1987, Powell \& Arp 1989, Vismann 1990). The ecological significance of hydrogen sulfide is also demonstrated in comparative studies on meiofauna, polychaetes, crustaceans and fishes (Vargo \& Sastry 1978, Powell et al. 1979, Vetter et al. 1987, Bagarinao \& Vetter 1989, 1990, Vismann 1990).

Tolerance to hydrogen sulfide (excluding species 
with symbiotic sulfide-oxidizing bacteria) may be achieved by the following mechanisms: (1) exclusion of hydrogen sulfide; (2) possession of a cytochrome oxidase and an oxygen-transporting blood pigment which are insensitive to hydrogen sulfide; (3) dependence on anaerobic energy metabolism; (4) detoxification of hydrogen sulfide.

Detoxification can be effected by (1) enzymatic oxidation of hydrogen sulfide to non-toxic sulfur compounds; (2) non-enzymatic oxidation by metallic ions or metallo-protein complexes; (3) immobilization of hydrogen sulfide by binding to compounds such as metallic ions or proteins. Especially ferrous iron (e.g. Buchanan et al. 1980, De Ridder et al. 1985) and the tripeptide glutathione (e.g. Smith \& Abbanat 1966, Siegel 1975) have been suggested as taking part in the detoxification of hydrogen sulfide.

Crustaceans are generally not tolerant to low oxygen tensions, but the few species which are tolerant to hypoxia my also be tolerant to hydrogen sulfide. Detoxification of sulfide has been demonstrated in some crustaceans from sulfide-rich environments (Vargo \& Sastry 1978, Vetter et al. 1987). In the species studied by Vetter et al. (1987), sulfide detoxification takes place in the hepatopancreas. In crustaceans, this organ consists of one to several pairs of bilaterally arranged mesenteric glandular appendages extending from the midgut. The hepatopancreas is an exocrine gland excreting numerous enzymes into its extracellular lumen, where many metabolic activities are known to occur, including digestion and detoxification of poisonous substances (see e.g. Gibson \& Barker 1979).

The isopod Saduria (Mesidotea) entomon (L.) is an example of an invertebrate living in an environment with high risk of exposure to external sulfide. $S$. entomon is a scavenger and burrows in sandy or muddy sediments, but it does not construct tubes. In the Baltic Sea it is an important faunal component, both as a consumer and as a food item for cod (Haathela 1962). As shown by Hagerman \& Szaniawska (1988, 1990) $S$. entomon is very tolerant to hypoxia/anoxia.

The purpose of the present work was to elucidate physiological mechanisms involved in sulfide detoxification in Saduria entomon. The study included in vitro as well as in vivo experiments. The questions I attempted to answer were the following: (1) In which tissues and at what rates is hydrogen sulfide detoxified? (2) What is the chemical nature of the detoxification? Using intact isopods it was further investigated whether hydrogen sulfide can be prevented from entering the organism, and how the concentrations of hydrogen sulfide, glutathione, and detoxification products vary in different tissues during exposure to hydrogen sulfide.

\section{MATERIALS AND METHODS}

Sampling. Saduria entomon was collected at depths exceeding $15 \mathrm{~m}$ in the Gulf of Gdańsk, Poland (salinity 7 to $8 \%$, temperature $8{ }^{\circ} \mathrm{C}$ ) and in the area between Scania and Bornholm, Denmark ( 7 to $8 \% \mathrm{~S}, 8^{\circ} \mathrm{C}$ ). The specimens were transported to the laboratory in Helsingør, Denmark, and kept at constant temperature $\left(6^{\circ} \mathrm{C}\right)$ in large tanks with natural sediment and aerated water $(7 \%$ S) until experiments started. The isopods were fed once weekly with bivalve meat. The crustacean Carcinus maenas, which lives in sulfide-free habitats, was used as a control in the sulfide oxidation activity analysis. C. maenas was collected in the Kattegat, Denmark.

The specimens used in analysis were dried and blood samples taken by carefully inserting a $100 \mu$ hypodermic syringe (Terumo) into the heart from a posterodorsal direction. The carapace was removed and tissue samples were taken. The hepatopancreas of Saduria entomon consists of 3 pairs of glandular appendages. Each appendage was removed with its contents using a pair of forceps to lift the organ at the area where it opens into the midgut. The fluid component of the gland was obtained by puncturing the gland, allowing the fluid to drain out. The cellular component of the gland was carefully washed before analysis. During the experiments it was noted that the hepatopancreas of the specimens used showed differences in color. The hepatopancreas of the control groups and the hypoxic groups were in general white to yellow in color, whereas the hepatopancreas of the sulfide-exposed individuals all had turned black.

Sulfide oxidation activity. Tissue samples of Saduria entomon and Carcinus maenas were homogenized on ice in a buffer ( $\mathrm{pH} 8.0,50 \mathrm{mM}$ Tris/ $\mathrm{HCl}$ and $0.1 \%$ of the laboratory detergent 'Prox'). The samples were centrifuged for $10 \mathrm{~min}$ at $10000 \times \mathrm{g}$. Sulfide oxidation of the supernatant was measured colormetrically using benzyl viologen (1.1'dibenzyl-4.4'-bipyridinium). The reaction mixture contained $40 \mathrm{mM}$ glycine/ $\mathrm{NaOH}$ buffer ( $\mathrm{pH} 9.0$ ), $2 \mathrm{mM}$ benzyl viologen, 0 to $5 \mathrm{mM} \mathrm{Na}_{2} \mathrm{~S}$, and 200 ul sample in a total volume of $2 \mathrm{ml}$. The method is basically that of Powell \& Somero (1985) as modified by Vismann (1990).

Elemental sulfur. Elemental sulfur was analyzed by high-performance liquid chromatography (HPLC) using 1 pump (Jasco 880 PU), a manual injector (Rheodyne 7105) fitted with a $20 \mu \mathrm{l}$ loop, and a UV/VIS detector (Jasco 875-UV) set at $254 \mathrm{~nm}$. The column was a Hamilton PRP-1 reversed phase column $15 \mathrm{~cm} \times$ $4.1 \mathrm{~mm}$ i.d.). Treatment of the column prior to analysis, extraction of samples in chloroform followed by uptake in methanol, and the HPLC protocol were performed according to Lauren \& Watkinson (1985). 
Thiols. Monobromobimane (mBBr) and primary thiols form fluorescent adducts (mBSR), which can be separated by HPLC (e.g. Fahey \& Newton 1987, Vetter et al. 1989). Tissue samples were rapidly homogenized on ice in a deoxygenated buffer $[200 \mathrm{mM}$ HEPES (N-2hydroxyethyl piperazine-N'-2-ethane sulfonic acid) and $5 \mathrm{mM}$ EDTA; $\mathrm{pH} 8.0$ ] with a sonicator (Mullard $7685 / 2)$. The homogenate $(100 \mu \mathrm{l})$ was added to $10 \mu \mathrm{l}$ $\mathrm{mBBr}(70 \mathrm{mM})$. The mixture was allowed to derivatizate in darkness for $15 \mathrm{~min}$. Proteins were precipitated by addition of $100 \mu \mathrm{l}$ acetonitrile followed by heating $\left(60^{\circ} \mathrm{C}\right)$ for $10 \mathrm{~min}$. Finally, $200 \mu \mathrm{l}$ of the mixture was combined with $300 \mu$ methane sulfonic acid $(25 \mathrm{mM}$; $\mathrm{pH} 3.9)$ to dilute the acetonitrile and to stabilize the sample. Samples which were not analyzed immediately were stored at $-20^{\circ} \mathrm{C}$ until analysis (max. $30 \mathrm{~d}$ ). No significant effect on sample fluorescence has been shown for storage up to 20 mo at $+4,-20$ or $-70^{\circ} \mathrm{C}$ (Fahey \& Newton 1987). The samples were centrifuged at $15000 \times g$ for $10 \mathrm{~min}$ before the HPLC analysis.

Thiols were analyzed by HPLC via 2 pumps (Jasco 880 PU), a manual injector (Rheodyne 7105) fitted with a $20 \mu \mathrm{l}$ loop, a solvent mixing module (Jasco 880-31) and a fluorescence detector (Perkin-Elmer LC 1000, excitation $=395 \mathrm{~nm}$, emission $=480 \mathrm{~nm}$ ). The fluorescence detector output $(\mathrm{mV}$ ) was logged on a computer with $2 \mathrm{~s}$ intervals. HPLC separation was carried out on a Spherisorb column (S5 ODS1; $25 \mathrm{~cm} \times 4.6 \mathrm{~mm}$ i.d.).

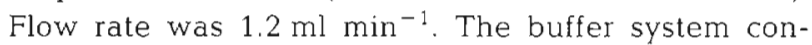
sisted of 2 buffers: Buffer A, 10\% methanol and $0.25 \%$ acetic acid; Buffer B, $90 \%$ methanol and $0.25 \%$ acetic acid. Both buffers were prepared in glass-distilled water. The buffers were adjusted to $\mathrm{pH} 3.9$, filtered and stripped of air bubbles. The elution profile was as follows: 0 to $10 \mathrm{~min}$ : $8 \%$ Buffer B (isocratic); 10 to 20 min: 8 to $40 \%$ Buffer B (linear gradient); 20 to $25 \mathrm{~min}$ : $40 \%$ Buffer B (isocratic); 25 to 30 min: 40 to $90 \%$ Buffer $B$ (linear gradient). Elution was followed by column regeneration: 30 to $32 \mathrm{~min}$ : 90 to $100 \%$ Buffer B (linear gradient); 32 to $35 \mathrm{~min}$ : $100 \%$ Buffer B (isocratic); 35 to 45 min: $8 \%$ Buffer B (isocratic).

Peaks of hydrogen sulfide $\left(\mathrm{H}_{2} \mathrm{~S}\right)$, thiosulfate $\left(\mathrm{S}_{2} \mathrm{O}_{3}{ }^{2-}\right)$, sulfite $\left(\mathrm{SO}_{3}{ }^{2-}\right)$ and reduced glutathione (GSH) were integrated on the digitalized chromatograms and converted to concentration (per gram tissue) by a computer. Identification and conversion for each protocol were based on chromatograms of standard solutions ( 0 to $1 \mathrm{mM}$ ) and controls (Vetter et al. 1989).

In vivo exposure to $\mathbf{H}_{2} \mathbf{S}$. Saduria entomon were exposed to $\mathrm{H}_{2} \mathrm{~S}$ in an aquarium (30 l) with natural sediment. A $10 \mathrm{mM}$ sulfide stock solution (covered with paraffin oil to prevent gas diffusion and made fresh every day) was continuously pumped into the aquarium by a peristaltic pump (Gilson 312). The aquarium was aerated with nitrogen and atmospheric air. The water in the aquarium was covered with small plastic spheres. With this experimental set-up it was possible to control both oxygen tension and $\mathrm{H}_{2} \mathrm{~S}$ concentration. Oxygen was monitored using a polarographic oxygen sensor (Radiometer, E 5047) connected to a Radiometer PHM 73 acid-base analyzer. The electrode was only used for short intervals to avoid $\mathrm{H}_{2} \mathrm{~S}$ contamination of the electrode. $\mathrm{H}_{2} \mathrm{~S}$ concentration was monitored continuously with an Ag-AgS electrode connected to a potentiometer (Radiometer, Ion85) with a calomel electrode as reference. In addition, sulfide concentration was analyzed with HPLC during the experiments.

\section{RESULTS}

\section{In vitro experiments}

Sulfide oxidation activity

Sulfide oxidation activity in different tissues of Saduria entomon incubated at $5 \mathrm{mM}$ sulfide is shown in Table 1. The highest oxidation activity was found in the hepatopancreas, while oxidation activity in homogenates of muscle and blood was not significantly higher than the biological basal level (ca 0.20 to 0.25 umol min ${ }^{-1} \mathrm{~g}^{-1}$; see Powell \& Somero 1985 and Vismann 1990). The activity of gill homogenate was just above the basal level. Sulfide oxidation in the cellular and fluid components of the hepatopancreas showed that most of the oxidation was confined to the fluid component (Table 1). For comparison, sulfide oxidation in the hepatopancreas of Carcinus maenas from a sulfide-free habitat is also shown. Sulfide oxidation activity was tested for saturation kinetics in the hepatopancreas components in $S$. entomon (data not shown); sulfide oxidation activity in the cellular component was very low and regression analysis did not indicate saturation kinetics. Thus, the sulfide oxidation activity of the cellular component represented a non-specific oxidation. In the fluid components, however, the relation between substrate concentration and activity is well described by the Monod function $\left(\mathrm{R}^{2}=0.99, \mathrm{p}<0.001\right.$, $\mathrm{n}=10$ ), indicating presence of a catalyst with a halfsaturation constant $\left(K_{m}\right)$ and a maximal catalytic rate $\left(V_{\max }\right.$ ) of $0.52 \mathrm{mM}$ and $128.35 \mu \mathrm{mol} \mathrm{min}{ }^{-1} \mathrm{~g}^{-1}$, respectively. However, there was a very large discrepancy between the results with benzyl viologen and those obtained with HPLC (see below and 'Discussion').

\section{Sulfide removal and oxidation products}

The change in reduced sulfur in homogenates of the fluid component of the hepatopancreas incubated with 
Table 1 Saduria entomon and Carcinus maenas. Sulfide oxidation activity at $5 \mathrm{mM} \mathrm{H}_{2} \mathrm{~S}$ in homogenates of different tissues. Activities are expressed in $. . \mathrm{mol} \mathrm{min}^{-1} \mathrm{~g}^{-1} \pm$ SEM. Number of samples in parentheses

\begin{tabular}{|llc|}
\hline Species & Tissue & Mean sulfide oxidation \\
\hline S. entomon & Gill (11) & $0.36 \pm 0.06$ \\
& Muscle (8) & $0.31 \pm 0.06$ \\
& Blood (12) & $0.19 \pm 0.04$ \\
& Midtgut fluid (2) & $7.60 \pm 0.11$ \\
& Hepatopancreas (8) & $33.38 \pm 8.11$ \\
& Cellular component of hepatopancreas (14) & $2.27 \pm 0.26$ \\
C. maenas & Hepatopancreas (8) component of hepatopancreas (7) & $104.88 \pm 27.63$ \\
& Cellular component of hepatopancreas (3) & $0.78 \pm 0.12$ \\
& Fluid component of hepatopancreas (3) & $0.43 \pm 0.10$ \\
\hline
\end{tabular}

$1 \mathrm{mM} \mathrm{H}_{2} \mathrm{~S}$ (under an oxygen tension $\mathrm{p}_{\mathrm{w}} \mathrm{O}_{2}=145$ torr) in relation to time is seen in Fig. 1. Elemental sulfur was not measurable in any in vitro or in vivo experiments (detection limit with $20 \mu$ injection: 1 to $3 \mathrm{ng}$ (Lauren \& Watkinson 1985)]. Thus, this compound has been omitted from all tables and figures. In Fig. 1, the slope of regression lines gives the rate of $\mathrm{H}_{2} \mathrm{~S}$ removal and of $\mathrm{SO}_{3}{ }^{2-}$ and $\mathrm{S}_{2} \mathrm{O}_{3}{ }^{2-}$ accumulation (Table 2). When corrected for the corresponding control, $\mathrm{H}_{2} \mathrm{~S}$ was removed at a rate of $4.44 \mu \mathrm{mol} \mathrm{min}{ }^{-1} \mathrm{~g}^{-1}$, and the accumulation rate of $\mathrm{SO}_{3}{ }^{2-}$ and $\mathrm{S}_{2} \mathrm{O}_{3}{ }^{2-}$ was 1.18 and $1.42 \mu \mathrm{mol} \mathrm{min}{ }^{-1}$ $\mathrm{g}^{-1}$, respectively. About $60 \%$ of the $\mathrm{H}_{2} \mathrm{~S}$ removed was oxidized to $\mathrm{SO}_{3}{ }^{2-}$ and $\mathrm{S}_{2} \mathrm{O}_{3}{ }^{2-}$. The fraction of $\mathrm{H}_{2} \mathrm{~S}$ removed and not recovered as $\mathrm{SO}_{3}{ }^{2-}$ or $\mathrm{S}_{2} \mathrm{O}_{3}{ }^{2-}$ was 1.84 umol $\mathrm{min}^{-1} \mathrm{~g}^{-1}$ The possibility that this fraction was oxidized to $\mathrm{SO}_{4}{ }^{2-}$ was tested in an additional incubation, in which $\mathrm{O}_{2}$-dependent oxidation was inhibited by a low oxygen tension $\left(\mathrm{p}_{\mathrm{w}} \mathrm{O}_{2}<1\right.$ to 2 torr $)$ in the medium. Rates of $\mathrm{H}_{2} \mathrm{~S}$ removal and of $\mathrm{SO}_{3}{ }^{2-}$ and $\mathrm{S}_{2} \mathrm{O}_{3}{ }^{2-}$ production in this hypoxic incubation are given in Table 2. Inhibition of $\mathrm{SO}_{3}{ }^{2-}$ and $\mathrm{S}_{2} \mathrm{O}_{3}{ }^{2-}$ production was clearly seen. However, the $\mathrm{H}_{2} \mathrm{~S}$ removed and not recovered as $\mathrm{SO}_{3}{ }^{2-}$ or $\mathrm{S}_{2} \mathrm{O}_{3}{ }^{2-}$ in the hypoxic incubation amounted to $1.49 \mu \mathrm{mol} \mathrm{min}{ }^{-1} \mathrm{~g}^{-1}$, which is not significantly different from the $1.84 \mu \mathrm{mol} \mathrm{min} \mathrm{m}^{-1} \mathrm{~g}^{-1}$ in the normoxic incubation. Thus, it is most likely that the $\mathrm{H}_{2} \mathrm{~S}$ removed and not oxidized to $\mathrm{SO}_{3}{ }^{2-}$ and $\mathrm{S}_{2} \mathrm{O}_{3}{ }^{2-}$ is turned into something other than $\mathrm{SO}_{4}{ }^{2-}$ In a methodological test, either methane sulfonic acid ( $\mathrm{pH}$ 3.9) or HEPES buffer ( $\mathrm{pH} 8.0$ ) were added to subsamples of homogenate of $\mathrm{H}_{2} \mathrm{~S}$-exposed hepatopancreas. The subsamples were immediately analyzed by HPLC. It was observed that the acidic samples showed $40.9 \pm$ $14.6 \%$ higher $\mathrm{H}_{2} \mathrm{~S}$ content compared to the alkaline samples (data not shown), i.e. Ca $40 \%$ of the $\mathrm{H}_{2} \mathrm{~S}$ measured was acid labile $\mathrm{H}_{2} \mathrm{~S}$. Thus, in addition to the 4.44 umol min ${ }^{-1} \mathrm{~g}^{-1}$ of $\mathrm{H}_{2} \mathrm{~S}$ removed, some $\mathrm{H}_{2} \mathrm{~S}$ is immobilized as acid labile $\mathrm{H}_{2} \mathrm{~S}$.

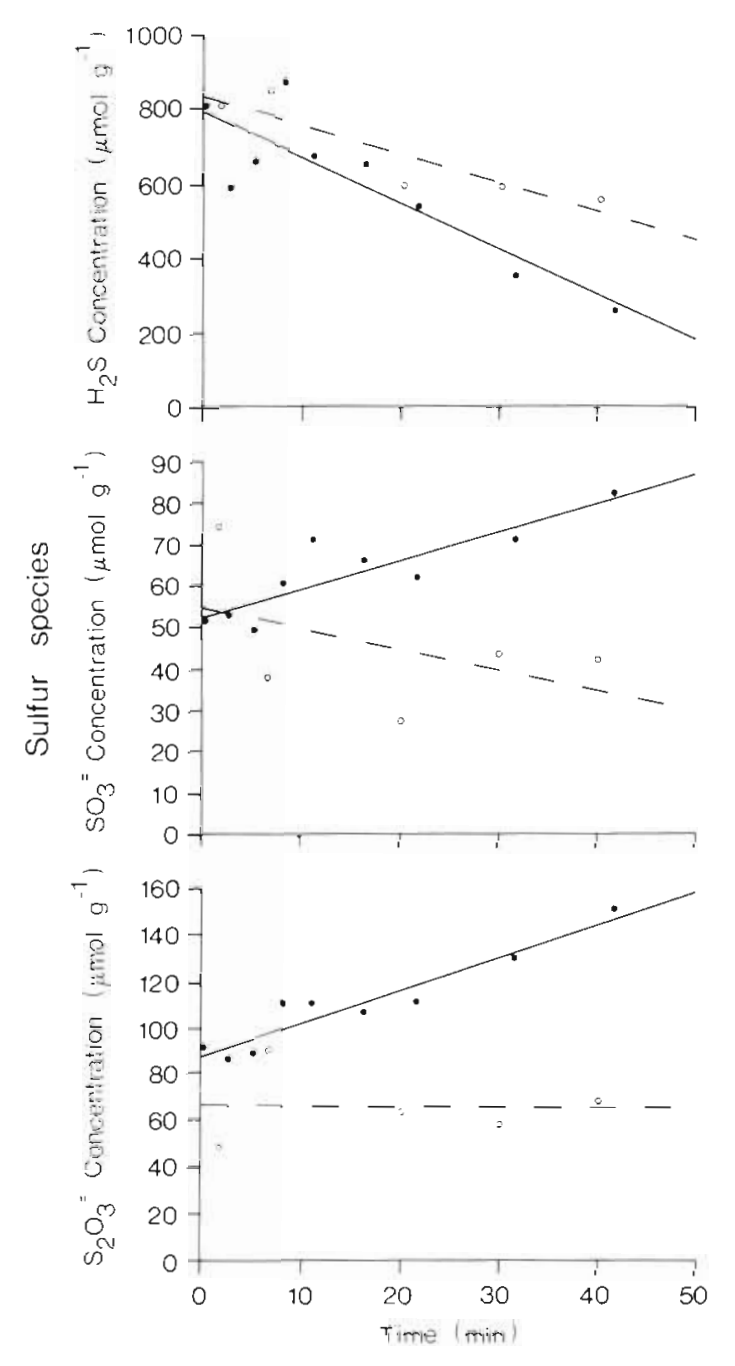

Fig. 1. Saduria entomon. Concentration of $\mathrm{H}_{2} \mathrm{~S}_{1} \mathrm{SO}_{3}{ }^{2-}$, and $\mathrm{S}_{2} \mathrm{O}_{3}{ }^{2-}$ in homogenates of the fluid component of hepatopancreas in isopods incubated with $1 \mathrm{mM} \mathrm{H}_{2} \mathrm{~S}$, as a function of time. ( $\bullet$ ) Hepatopancreas, (f) control. Solid and broken lines are calculated best-fit straight lines of hepatopancreas and control, respectively 
Heat stability of the sulfide oxidation

The occurrence of enzymatic catalysis of sulfide oxidation in the hepatopancreas fluid was tested in a number of heat stability experiments. The rate of $\mathrm{H}_{2} \mathrm{~S}$ removal and of $\mathrm{SO}_{3}{ }^{2-}$ and $\mathrm{S}_{2} \mathrm{O}_{3}{ }^{2-}$ accumulation in a sample (fractionated into a heated $\left(30 \mathrm{~min}\right.$ at $\left.100^{\circ} \mathrm{C}\right)$ and a non-heated sample] exposed to $1 \mathrm{mM}$ sulfide is shown in Table 2. Accumulation of $\mathrm{SO}_{3}{ }^{2-}$ and $\mathrm{S}_{2} \mathrm{O}_{3}{ }^{2-}$ under normoxia was seen to decrease by ca 30 and $38 \%$, respectively, in the heated sample. In the heated and unheated hypoxic incubations the same trend was observed regarding $\mathrm{S}_{2} \mathrm{O}_{3}{ }^{2-}$ accumulation. The decrease in $\mathrm{SO}_{3}{ }^{2-}$ and $\mathrm{S}_{2} \mathrm{O}_{3}{ }^{2-}$ accumulation in the heated samples indicates the occurrence of enzymatic $\mathrm{H}_{2} \mathrm{~S}$ oxidation. Removal of $\mathrm{H}_{2} \mathrm{~S}$ in the heated samples was significantly increased in both the normoxic and the hypoxic incubations. Thus, denatured proteins and metallic ions, which may be more available in the heated samples, seem to allow an increased non-specific binding of $\mathrm{H}_{2} \mathrm{~S}$. This, together with the pool of acid labile $\mathrm{H}_{2} \mathrm{~S}$ and the color change in the hepatopancreas of sulfide-exposed individuals, suggests the presence of iron in the fluid component of the hepatopancreas.

\section{In vivo experiments}

Exclusion of sulfide from the organism

$\mathrm{H}_{2} \mathrm{~S}$ concentration in the blood of isopods adapted to severe hypoxia ( $3 \pm 2$ torr) for $10 \mathrm{~d}$ and then exposed to a slowly increasing sulfide concentration is shown in Fig. 2. Regression lines of $\mathrm{H}_{2} \mathrm{~S}$ concentration in the blood and water, respectively, as a function of time are given by: intercept $=1.73 \pm 0.85 \mu \mathrm{mol} \mathrm{g}^{-1}$, slope $=$ $2.18 \pm 0.44 \mu \mathrm{mol} \mathrm{g}{ }^{-1} \mathrm{~h}^{-1}\left(\mathrm{R}^{2}=0.86, \mathrm{p}<0.01\right)$; and

Table 2. Saduria entomon. Rate of removal/production of $\mathrm{H}_{2} \mathrm{~S}$, $\mathrm{SO}_{3}{ }^{2-}$, and $\mathrm{S}_{2} \mathrm{O}_{3}{ }^{2-}$ of homogenate of the fluid component of hepatopancreas in isopods incubated with $1 \mathrm{mM} \mathrm{H}_{2} \mathrm{~S}$ at normoxia $\left(\mathrm{p}_{\mathrm{w}} \mathrm{O}_{2}=145\right.$ torr $)$ and hypoxia $\left(\mathrm{p}_{\mathrm{wr}} \mathrm{O}_{2}<1\right.$ to 2 torr $)$ before and after heating $\left(100^{\circ} \mathrm{C}\right.$ for $\left.30 \mathrm{~min}\right)$. Rates are expressed as $\mu \mathrm{mol}$ minin $^{-1} \mathrm{~g}^{-1} \pm \mathrm{SEM}$

\begin{tabular}{|lrrr|}
\hline Treatment & $\mathrm{SO}_{3}{ }^{2-}$ & \multicolumn{1}{c|}{$\mathrm{S}_{2} \mathrm{O}_{3}{ }^{2-}$} & $\mathrm{H}_{2} \mathrm{~S}$ \\
\hline Normoxia & & & \\
No heat & $0.68 \pm 0.14$ & $1.39 \pm 0.18$ & $-12.27 \pm 2.59$ \\
Heat & $-0.15 \pm 0.31$ & $0.51 \pm 0.29$ & $-19.85 \pm 5.51$ \\
Control & $-0.50 \pm 0.56$ & $-0.03 \pm 0.56$ & $-7.83 \pm 2.05$ \\
Hypoxia & & & \\
No heat & $0.01 \pm 0.03$ & $0.69 \pm 0.13$ & $-2.18 \pm 1.26$ \\
Heat & $0.09 \pm 0.06$ & $0.42 \pm 0.10$ & $-4.19 \pm 0.80$ \\
Control & $-0.03 \pm 0.05$ & $0.43 \pm 0.10$ & $-0.39 \pm 0.77$ \\
\hline
\end{tabular}

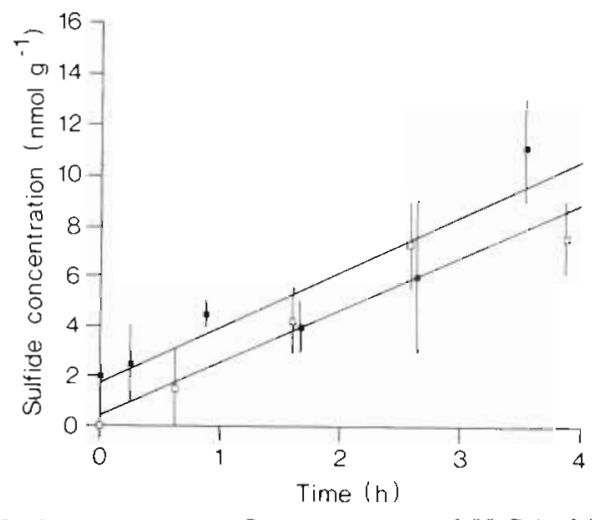

Fig. 2. Saduria entomon. Concentration of $\mathrm{H}_{2} \mathrm{~S}$ in blood as a function of increasing external $\mathrm{H}_{2} \mathrm{~S}$ concentration. ( Blood, ( $\omega)$ water. Best-fit straight lines calculated using a linear regression program. Data points represent triplicate measurements $\pm \mathrm{SE}$

intercept $=0.48 \pm 0.78 \mu \mathrm{mol} \mathrm{g}{ }^{-1}$, slope $=2.08 \pm 0.35$ $\mu \mathrm{mol} \mathrm{g}{ }^{-1} \mathrm{~h}^{-1}\left(\mathrm{R}^{2}=0.92, \mathrm{p}<0.01\right)$. The sulfide concentration in the blood reflected the environmental concentration, so it was not possible for Saduria entomon to prevent sulfide from entering its body.

\section{Natural levels of $\mathrm{H}_{2} \mathrm{~S}, \mathrm{SO}_{3}{ }^{2-}, \mathrm{S}_{2} \mathrm{O}_{3}{ }^{2-}$, and GSH}

Natural levels of reduced sulfur compounds in Saduria entomon kept for $10 \mathrm{~d}$ at normoxia (145 \pm 12 torr) and hypoxia ( $3 \pm 2$ torr) are shown in Figs. $3 \& 4$. No significant difference $(p>0.05)$ in the levels of $\mathrm{H}_{2} \mathrm{~S}$, $\mathrm{SO}_{3}{ }^{2-}$, and $\mathrm{S}_{2} \mathrm{O}_{3}{ }^{2-}$ was seen between normoxia and hypoxia in any of the tissues (Fig. 3). In the blood, all levels of $\mathrm{H}_{2} \mathrm{~S}, \mathrm{SO}_{3}{ }^{2-}$, and $\mathrm{S}_{2} \mathrm{O}_{3}{ }^{2-}$ were on average $<2$ nmol $\mathrm{g}^{-1}$, except that $\mathrm{S}_{2} \mathrm{O}_{3}{ }^{2-}$ was ca $8 \mathrm{nmol} \mathrm{g}^{-1}$ at hypoxia. In the muscle the average levels of $\mathrm{H}_{2} \mathrm{~S}$, $\mathrm{SO}_{3}{ }^{2-}$, and $\mathrm{S}_{2} \mathrm{O}_{3}{ }^{2-}$ were ca 13,30 , and $150 \mathrm{nmol} \mathrm{g}^{-1}$ respectively. In the hepatopancreas average levels were ca 50,100, and $35 \mathrm{nmol} \mathrm{g}^{-1}$ respectively. Levels of GSH between normoxia and hypoxia in blood and hepatopancreas were not significantly different (p $>0.05$ ). In the muscle, however, a significant difference $(\mathrm{p}<0.05)$ was observed between normoxia and hypoxia. The average level of GSH in blood and hepatopancreas was ca 20 and $2400 \mathrm{nmol} \mathrm{g}^{-1}$ respectively. In the muscle, GSH level under normoxia (ca 360 $\mathrm{nmol} \mathrm{g}^{-1}$ ) increased to ca $1200 \mathrm{nmol} \mathrm{g}^{-1}$ under hypoxia.

Reduced sulfur compounds in relation to hypoxia and $\mathrm{H}_{2} \mathrm{~S}$ exposure

Levels of reduced sulfur compounds in isopods kept for $10 \mathrm{~d}$ under hypoxia followed by $1 \mathrm{~d}$ of exposure to $\mathrm{H}_{2} \mathrm{~S}(80 \mu \mathrm{M})$ are shown in Figs $3 \& 4$. When comparing 


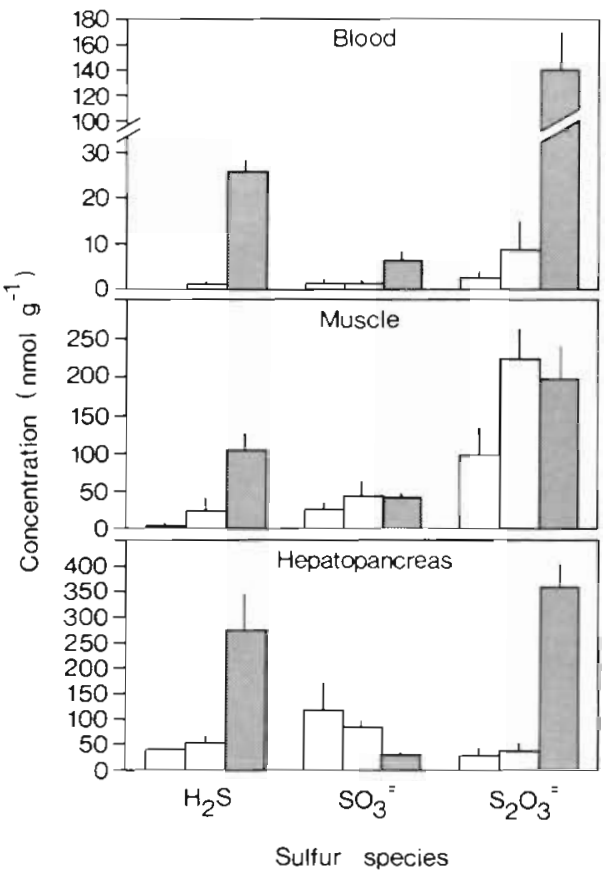

Fig. 3. Saduria entomon. Concentration of $\mathrm{H}_{2} \mathrm{~S}, \mathrm{SO}_{3}{ }^{2-}$, and $\mathrm{S}_{2} \mathrm{O}_{3}{ }^{2-}$ in different tissues of isopods $(\mathrm{n}=5)$ as a function of $\mathrm{p}_{\mathrm{w}} \mathrm{O}_{2}$ with/without $\mathrm{H}_{2} \mathrm{~S}$. Specimens were adapted to experimental $\mathrm{p}_{\mathrm{w}} \mathrm{O}_{2}$ conditions for $10 \mathrm{~d}$ prior to analysis. Open bars: 145 torr; light gray bars: 3 torr; dark gray bars: 3 torr $+80 \mu \mathrm{M}$ $\mathrm{H}_{2} \mathrm{~S}$. Standard error bars also shown

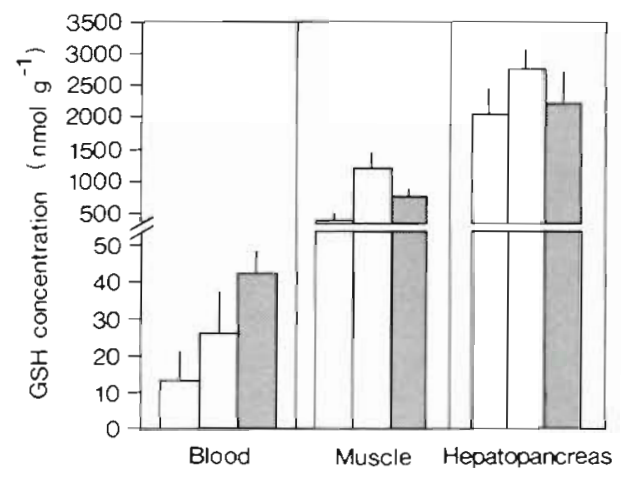

Fig. 4. Saduria entomon. Concentration of GSH in different tissues of isopods $(n=5)$ as a function of $\mathrm{p}_{\mathrm{w}} \mathrm{O}_{2}$ with/without $\mathrm{H}_{2} \mathrm{~S}$. Specimens were adapted to the experimental $\mathrm{p}_{\mathrm{w}} \mathrm{O}_{2}$ for $10 \mathrm{~d}$ prior to analysis. Bars as in Fig. 3

specimens under hypoxia with and without $\mathrm{H}_{2} \mathrm{~S}$, all tissues showed higher $\mathrm{H}_{2} \mathrm{~S}$ levels when exposed to $\mathrm{H}_{2} \mathrm{~S}$ (blood, $p<0.000001$; muscle, $p<0.01$; hepatopancreas, $\mathrm{p}<0.05$ ). No significant differences were found in the levels of $\mathrm{SO}_{3}{ }^{2-}$. However, $\mathrm{S}_{2} \mathrm{O}_{3}{ }^{2-}$ accumulated in blood $(\mathrm{p}<0.01)$ and hepatopancreas $(\mathrm{p}<0.001)$ during $\mathrm{H}_{2} \mathrm{~S}$ exposure, and the concentration of $\mathrm{H}_{2} \mathrm{~S}$ in blood, muscle, and hepatopancreas increased from natural levels to ca 25,100 , and $275 \mathrm{nmol} \mathrm{g}^{-1}$ respectively. In fact, the hepatopancreas concentrates $\mathrm{H}_{2} \mathrm{~S}$. No significant differences in GSH levels of any tissue were observed between specimens under hypoxia with and without $\mathrm{H}_{2} \mathrm{~S}$.

Reduced sulfur compounds in relation to duration of $\mathrm{H}_{2} \mathrm{~S}$ exposure

Concentrations of $\mathrm{H}_{2} \mathrm{~S}_{1} \mathrm{SO}_{3}{ }^{2-}, \mathrm{S}_{2} \mathrm{O}_{3}{ }^{2-}$, and $\mathrm{GSH}$ in tissues exposed to $\mathrm{H}_{2} \mathrm{~S}$ and hypoxia $(3 \pm 2$ torr) are shown in Figs. 5 \& 6 . Mean concentrations of $\mathrm{H}_{2} \mathrm{~S}$, $\mathrm{SO}_{3}{ }^{2-}, \mathrm{S}_{2} \mathrm{O}_{3}{ }^{2-}$, and $\mathrm{GSH}$ in the water were $1.57 \pm$ $0.20 \mathrm{mM}, 0.03 \pm 0.01 \mathrm{mM}, 0.11 \pm 0.03 \mathrm{mM}$, and not detectable, respectively. Each data point in these 2 figures represents the mean of 3 different individuals, as animals were killed when analyzed. Hence, the standard error bars are relatively high, and the results are only considered as trends. $\mathrm{H}_{2} \mathrm{~S}_{1} \mathrm{SO}_{3}{ }^{2-}$ and $\mathrm{S}_{2} \mathrm{O}_{3}{ }^{2-}$ in the blood accumulated slowly to ca $0.5,0.10$ and $0.25 \mu \mathrm{mol} \mathrm{g}{ }^{-1}$, respectively, at the end of the experiment. In the muscle, $\mathrm{H}_{2} \mathrm{~S}$ increased during the experiment to reach a concentration of ca $0.75 \mu \mathrm{mol} \mathrm{g}^{-1}$. $\mathrm{SO}_{3}{ }^{2-}$ and $\mathrm{S}_{2} \mathrm{O}_{3}{ }^{2-}$ concentrations in the muscle increased to a steady level $\left(0.25\right.$ and $1 \mu^{-m_{0 l} g^{-1}}$ respectively) within $1 \mathrm{~h}$. As in the muscle, the trend in $\mathrm{SO}_{3}{ }^{2-}$ concentration in the hepatopancreas reached a steady level of $0.25 \mu \mathrm{mol} \mathrm{g}{ }^{-1}$ within $1 \mathrm{~h}$. In the hepatopancreas, $\mathrm{H}_{2} \mathrm{~S}$ and $\mathrm{S}_{2} \mathrm{O}_{3}{ }^{2-}$ increased during the first $400 \mathrm{~min}$ of $\mathrm{H}_{2} \mathrm{~S}$ exposure, but tended to decrease during the last 300 min of the experiment. GSH (Fig. 6) in the blood increased slowly during the first $500 \mathrm{~min}$ of $\mathrm{H}_{2} \mathrm{~S}$ exposure and at a higher rate thereafter. After 100 min of $\mathrm{H}_{2} \mathrm{~S}$ exposure, GSH in the muscle increased

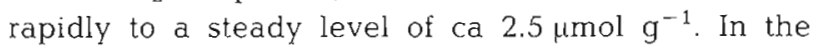
hepatopancreas, GSH concentration quickly increased to a level of ca $7 \mu \mathrm{mol} \mathrm{g}{ }^{-1}$, which was maintained until $300 \mathrm{~min}$ of $\mathrm{H}_{2} \mathrm{~S}$ exposure. During the last $400 \mathrm{~min}$ of the experiment, GSH concentration in the hepatopancreas decreased. This decrease coincided with the decrease in $\mathrm{H}_{2} \mathrm{~S}$ and $\mathrm{S}_{2} \mathrm{O}_{3}{ }^{2-}$

\section{DISCUSSION}

Besides chemical transformation (detoxification) of $\mathrm{H}_{2} \mathrm{~S}$, the only strategies in marine invertebrates for avoiding poisoning are the selective exclusion of $\mathrm{H}_{2} \mathrm{~S}$, reliance upon anaerobic respiration or possession of $\mathrm{H}_{2} \mathrm{~S}$-insensitive enzymes. The crustacean gill is known to regulate ionic exchange (e.g. Lucu 1990). Selective exclusion of $\mathrm{H}_{2} \mathrm{~S}$ should, up to a critical concentration, result in lower $\mathrm{H}_{2} \mathrm{~S}$ concentration in the blood than in the external environment. To my knowledge, exclusion of $\mathrm{H}_{2} \mathrm{~S}$ has not been demonstrated in any invertebrate 


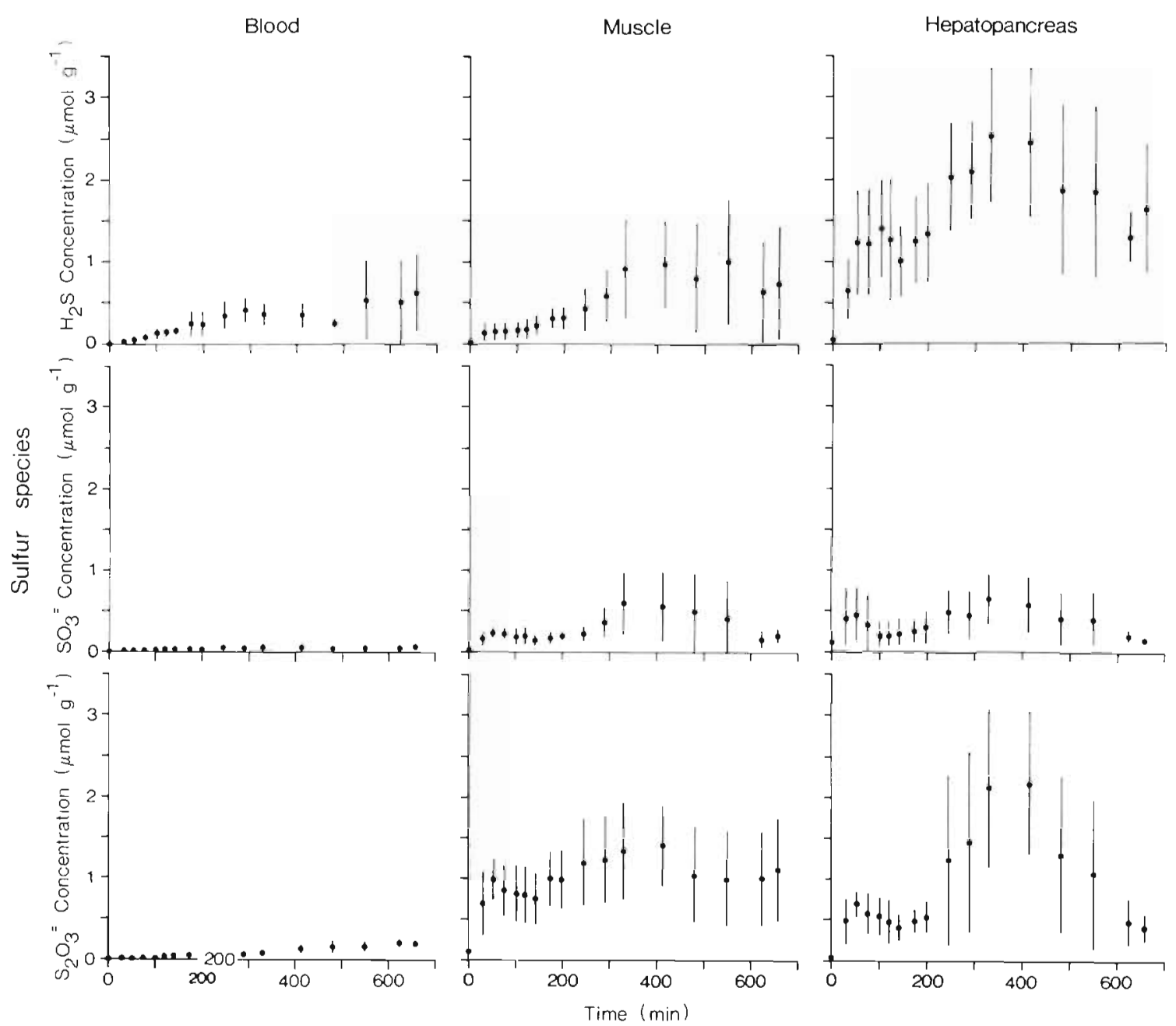

Fig. 5. Saduria entomon. Concentrations of $\mathrm{H}_{2} \mathrm{~S}_{1} \mathrm{SO}_{3}{ }^{2-}$, and $\mathrm{S}_{2} \mathrm{O}_{3}{ }^{2-}$ in different tissues of isopods exposed to $\mathrm{p}_{\mathrm{w}} \mathrm{O}_{2}=3$ torr and $1.57 \mathrm{mM} \mathrm{H}_{2} \mathrm{~S}$, as a function of time. Specimens were adapted to normoxia ( $\mathrm{p}_{\mathrm{w}} \mathrm{O}_{2}=145$ torr) for $10 \mathrm{~d}$ prior to the experiment. Each data point represents measurements for 3 individuals $\pm \mathrm{SE}$

(e.g. Powell et al. 1979, Vetter et al. 1987). In the present study, a linear increase in external $\mathrm{H}_{2} \mathrm{~S}$ concentration from ca $2 \mu \mathrm{M}$ to $10 \mu \mathrm{M}$ (Fig. 2) was instantaneously paralleled in the blood. If exclusion of $\mathrm{H}_{2} \mathrm{~S}$ is possible in Saduria entomon the $\mathrm{H}_{2} \mathrm{~S}$ concentration in the blood should be lower than that in the external environment, as only very low sulfide concentrations were used. $S$. entomon is therefore not able to prevent $\mathrm{H}_{2} \mathrm{~S}$ from entering its body.

Very few species are known to survive low oxygen tensions in the presence of $\mathrm{H}_{2} \mathrm{~S}$ on the basis of anaerobic respiration. In a study of the energy metabolism in vent fauna by Hand \& Somero (1983), animals (the clam Calyptogena magnifica excepted) were found to possess enzymes characteristic of aerobic respiration in amounts similar to those in animals from sulfide-free environments. During anoxia Saduria entomon accumulates lactate when forced to be active, but if left undisturbed it is quiescent and accumulates alanine instead (Hagerman \& Szaniawska 1990). S. entomon is one of the very few crustaceans which are adapted to long-term anaerobiosis. Hagerman \& Szaniawska (1990) found $S$. entomon to survive up to $300 \mathrm{~h}$ of anoxia. On the other hand, S. entomon has been shown to maintain stable aerobic respiration at decreasing $\mathrm{p}_{\mathrm{w}} \mathrm{O}_{2}$ down to $<5$ to 10 torr (Hagerman \& Szaniawska 1988). In practice, $S$. entomon must be considered able to extract all $\mathrm{O}_{2}$ from the water. Respiratory overshoot (indicating anaerobiosis during hypoxia) in $S$. entomon recovering from several hours of severe hypoxia was only seen occasionally by Hagerman \& Szaniawska (1988). In accordance with Hagerman \& Szaniawska (1988) it is assumed in the present study that $S$. entomon respires aerobically. Aerobic/anaerobic respiration and concentrations of metabolites with increasing hypoxia and/or presence of 


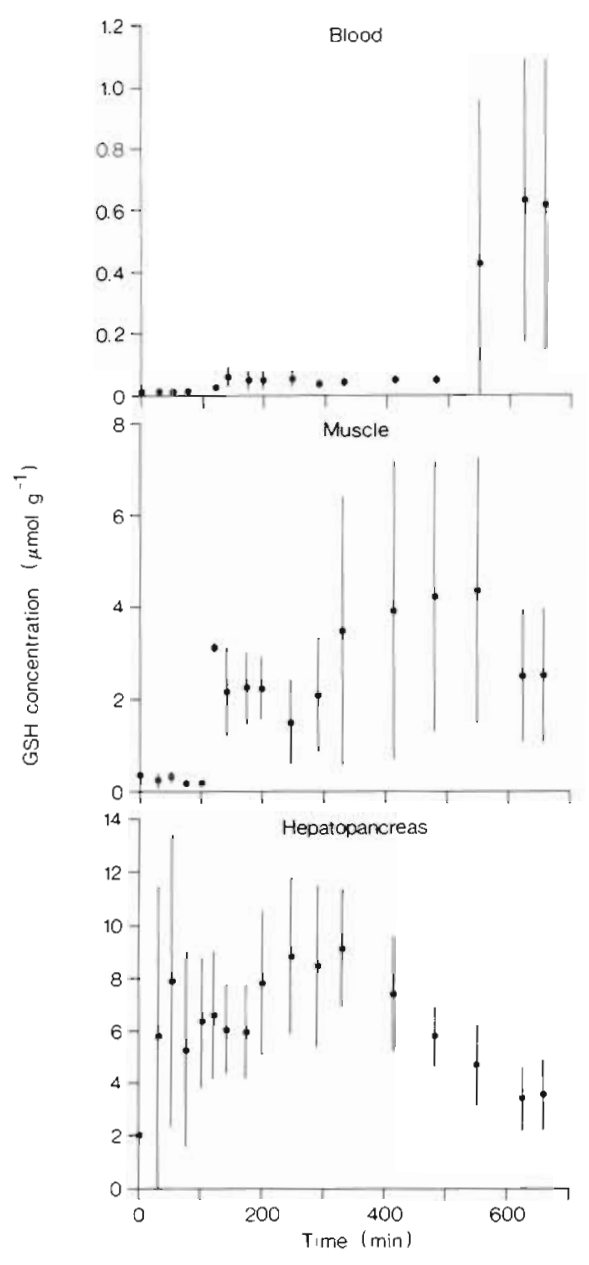

Fig. 6. Saduria entomon. Concentrations of GSH in different tissues of isopods exposed to $p_{\mathrm{w}} \mathrm{O}_{2}=3$ torr and $1.57 \mathrm{mM} \mathrm{H}_{2} \mathrm{~S}$. as a function of time. Specimens were adapted to normoxia $\left(\mathrm{p}_{\mathrm{w}} \mathrm{O}_{2}=145\right.$ torr $)$ for $10 \mathrm{~d}$ prior to the experiment. Each data point represents measurements for 3 individuals $\pm \mathrm{SE}$

$\mathrm{H}_{2} \mathrm{~S}$ are presently being studied by the author and L. Hagerman.

Saduria entomon exposed to a mixture of $\mathrm{O}_{2}$ and $\mathrm{H}_{2} \mathrm{~S}$ in the environment survives by detoxifying $\mathrm{H}_{2} \mathrm{~S}$ in the hepatopancreas. This has also been found for other sulfide-tolerant crustaceans (Vetter et al. 1987). The cellular component of the crustacean hepatopancreas is known to be involved in synthesis, storage, and secretion of enzymes, absorption of nutrients and excretion of waste products (Gibson \& Barker 1979). Although an intracellular phase of digestion has been demonstrated (Barker \& Gibson 1977), the activity of digestive enzymes is normally confined to the fluid component. It is thus physiologically plausible that enzymatic detoxification of $\mathrm{H}_{2} \mathrm{~S}$ is also confined to the fluid component of the gland.

Detoxification can be quantified as the rate of $\mathrm{H}_{2} \mathrm{~S}$ removal. The rate of sulfide removal measured with the benzyl viologen method is the highest ever measured (see e.g. Powell \& Somero 1985, 1986, Vetter et al. 1987, Bagarinao \& Vetter 1989, Vismann 1990). From data in Moriarty \& Nicholas (1969) sulfide oxidation in Thiobacillus concretivorus can be calculated to be ca 50 umol min $\mathrm{m}^{-1} \mathrm{~g}^{-1}$. In the bivalve Solemya reidi, the gills contain a high number of sulfide-oxidizing bacteria, and the gill sulfide oxidation activity has been found to be ca $6 \mu \mathrm{mol} \mathrm{min} \mathrm{m}^{-1} \mathrm{~g}^{-1}$ (Powell \& Somero 1985). Therefore, the sulfide oxidation rate as estimated with the benzyl viologen method seems unrealistically high. In addition, the benzyl viologen method has a number of shortcomings: (1) the method is performed with an anoxic reaction medium, making production of $\mathrm{SO}_{3}{ }^{2-}, \mathrm{S}_{2} \mathrm{O}_{3}{ }^{2-}$, or $\mathrm{SO}_{4}{ }^{2-}$ impossible; (2) it is an indirect method, in which nothing is known about the electron-producing reactions leading to color development ${ }_{i}$ (3) the $\mathrm{H}_{2} \mathrm{~S}$ concentration normally used (5 mM) exceeds realistic in vivo concentrations. In agreement with the conclusion reached by Bagarinao \& Vetter (1990), I regard the method as having no in vivo physiological significance. Although the $\mathrm{H}_{2} \mathrm{~S}$ removal rate estimated with HPLC is lower than that estimated with the benzyl viologen method by a factor of ca 10 , the hepatopancreas of Saduria entomon still removes $\mathrm{H}_{2} \mathrm{~S}$ at a very high rate. The benzyl viologen assay showed no sulfide oxidation activity in the muscle (Table 1). However, $\mathrm{S}_{2} \mathrm{O}_{3}{ }^{2-}$ was seen to accumulate in vivo in the muscles of isopods exposed to $1.5 \mathrm{mM} \mathrm{H}_{2} \mathrm{~S}$ (Fig. 5). According to Bagarinao \& Vetter (1990) any mitochondrial sulfide detoxification occurring in the muscle would be inhibited at the $\mathrm{H}_{2} \mathrm{~S}$ concentration used in the benzyl viologen assay. Thus, the in vivo experiment indicates that mitochondrial sulfide detoxification occurs in the muscle of $S$. entomon. This process appears to operate only above a threshold of external sulfide concentration, as no $\mathrm{S}_{2} \mathrm{O}_{3}{ }^{2-}$ accumulated in the muscle of individuals exposed in vivo to $80 \mathrm{\mu M} \mathrm{H}_{2} \mathrm{~S}$ (Fig. 3).

In the in vitro experiments, most of the $\mathrm{H}_{2} \mathrm{~S}$ removed by the hepatopancreas was oxidized to $\mathrm{S}_{2} \mathrm{O}_{3}{ }^{2-}$ and $\mathrm{SO}_{3}{ }^{2-}$ in an $\mathrm{O}_{2}$-dependent reaction. Specific catalysis of $\mathrm{H}_{2} \mathrm{~S}$ oxidation to $\mathrm{S}_{2} \mathrm{O}_{3}{ }^{2-}$ has also been found in rat liver and kidney (Baxter \& VanReen 1958a, Baxter et al. 1958, Sörbo 1958, 1960). However, the oxidation rates observed in these mammal studies are not higher than could be obtained by any low-molecular-weight iron chelate or iron-protein complex, e.g. ferritin or hemoglobin (Baxter \& VanReen 1958b, Sörbo 1958, Siegel 1975). The removal of $\mathrm{H}_{2} \mathrm{~S}$ and production of $\mathrm{S}_{2} \mathrm{O}_{3}{ }^{2-}$ observed in vitro by Baxter et al. (1958) was only ca $1 \%$ and $6 \%$, respectively, of the rates found in Saduria entomon.

Vertebrates are known to oxidize $\mathrm{H}_{2} \mathrm{~S}$ to $\mathrm{SO}_{4}{ }^{2-}$, which is excreted with the urine (e.g. Dziewiatkowski 
1945, Yokoyama et al. 1971, Curtis et al. 1972), and $\mathrm{S}_{2} \mathrm{O}_{3}{ }^{2-}$ is produced as an intermediate compound (see e.g. Baxter \& VanReen 1958a, Baxter et al. 1958, Sörbo 1958). Accumulation of $\mathrm{S}_{2} \mathrm{O}_{3}{ }^{2-}$, instead of $\mathrm{SO}_{4}{ }^{2-}$ excretion, has been demonstrated in several marine animals (e.g. Vetter et al. 1987, Bagarinao \& Vetter 1989, O'Brien \& Vetter 1990). A significant level of $\mathrm{SO}_{4}{ }^{2-}$ production is probably also absent in Saduria entomon. Compared to production of $\mathrm{SO}_{3}{ }^{2-}$ or $\mathrm{SO}_{4}{ }^{2-}$, that of $\mathrm{S}_{2} \mathrm{O}_{3}{ }^{2-}$ has the highest efficiency in terms of $\mathrm{H}_{2} \mathrm{~S}$ removed per $\mathrm{O}_{2}$ used. In the marine environment, the correlation between $\mathrm{H}_{2} \mathrm{~S}$ and low $\mathrm{O}_{2}$ availability makes $\mathrm{S}_{2} \mathrm{O}_{3}{ }^{2-}$ production the most likely $\mathrm{O}_{2}$-dependent mechanism of sulfide detoxification. The importance of $\mathrm{O}_{2}$ availability for oxidation products is demonstrated in comparative studies by Powell et al. $(1979,1980)$. When exposed to a mixture of $\mathrm{H}_{2} \mathrm{~S}$ and $\mathrm{O}_{2}$, the $\mathrm{O}_{2}$ dependent strategy of $\mathrm{S}$. entomon is to produce $\mathrm{S}_{2} \mathrm{O}_{3}{ }^{2-}$, which accumulates in the muscle and the blood since it has a low ability to cross membranes (Holmes \& Donaldson 1969). In the muscle and blood the accumulated $\mathrm{S}_{2} \mathrm{O}_{3}{ }^{2-}$ is likely to be slowly excreted or oxidized to $\mathrm{SO}_{4}{ }^{2-}$ when $\mathrm{H}_{2} \mathrm{~S}$ is no longer present. The fluid component of the hepatopancreas is a part of the external environment, and the $\mathrm{S}_{2} \mathrm{O}_{3}{ }^{2-}$ produced in the gland is likely to leave via the digestive system.

Approximately $40 \%$ of the $\mathrm{H}_{2} \mathrm{~S}$ removed by the hepatopancreas of Saduria entomon is removed by an $\mathrm{O}_{2}$-independent mechanism. The basis for this may be $\mathrm{H}_{2} \mathrm{~S}$ binding to metallic ions, metal-protein complexes, formation of disulfide bonds, or oxidation to linear polysulfides. The present results strongly suggest that sulfide is bound to iron. In several crustaceans, the hepatopancreas is known to accumulate iron (Gibson \& Barker 1979). In the priapulid worm Halicryptus spinulosus, iron present in the cuticular mucus coat is suggested to be a rechargeable buffer protecting against sulfide toxicity (Oeschger \& Janssen 1991). Although this buffer cannot account for the long-term protection against sulfide seen in $H$. spinulosus, it allows the animal to gain time for metabolic adaptations (Oeschger \& Janssen 1991). Iron has also been suggested to take part in binding of $\mathrm{H}_{2} \mathrm{~S}$ in echinoderms (Buchanan et al. 1980, De Ridder et al. 1985). I therefore suggest that a buffer is present in the hepatopancreas of $S$. entomon. This buffer represents an additional mechanism for eliminating $\mathrm{H}_{2} \mathrm{~S}$ toxicity.

In mice, $\mathrm{H}_{2} \mathrm{~S}$ has been shown to react with glutathione disulfide (GSSG) forming GSSH and GSH, which protect against acute $\mathrm{H}_{2} \mathrm{~S}$ toxicity (Smith \& Abbanat 1966). Reduced glutathione stimulates the oxidation of $\mathrm{S}_{2} \mathrm{O}_{3}{ }^{2-}$ to $\mathrm{SO}_{3}{ }^{2-}$, which in turn is oxidized to $\mathrm{SO}_{4}{ }^{2-}$ (Sörbo 1964, Koj \& Frendo 1967, Koj 1968). Glutathione is abundant in animal tissues and involved in numerous reactions (Meister 1975, 1983).
In cells in a normal state, glutathione predominantly occurs in the reduced form. Oxidized glutathione (GSSG) is rapidly reduced to GSH by enzymatic catalysis. These oxidation-reduction processes are important in avoiding disruption of the thiol status of cell membranes by oxidative stress (Kosower \& Kosower 1983). If the reaction between GSSG and $\mathrm{H}_{2} \mathrm{~S}$ occurs in vivo it would be observed as an increase in GSH concentration. The physiological significance of the process is uncertain, as only a limited amount of GSSG is present, and hypoxia itself has been shown to decrease GSSG formation (Siegel 1975, Jaeschke 1990). Although only significant in muscle tissue, the effect of hypoxia on GSSG formation was observed as an increase in GSH in all tissues of Saduria entomon (Fig. 4). Exposure to $80 \mu \mathrm{M} \mathrm{H} \mathrm{H}_{2} \mathrm{~S}$ of isopods adapted to hypoxia for $1 \mathrm{~d}$ did not change the GSH concentrations in any tissues, and they even tended to decrease. The effect of hypoxia on GSH makes it impossible to evaluate whether the increase in GSH seen in the other in vivo experiment (Fig. 6) was caused by hypoxia or reactions between $\mathrm{H}_{2} \mathrm{~S}$ and GSSG. The decrease in GSH and $\mathrm{S}_{2} \mathrm{O}_{3}{ }^{2-}$ in the hepatopancreas observed after $400 \mathrm{~min}$ of $\mathrm{H}_{2} \mathrm{~S}$ exposure (Figs. $5 \&$ 6) was not a GSH-stimulated oxidation of $\mathrm{S}_{2} \mathrm{O}_{3}{ }^{2-}$ to $\mathrm{SO}_{3}{ }^{2-}$, as no simultaneous increase in $\mathrm{SO}_{3}{ }^{2-}$ was seen. Since a decrease in GSH in the hepatopancreas was accompanied by an increase in blood $\mathrm{GSH}_{1}$ the observed trends after $400 \mathrm{~min}$ of $\mathrm{H}_{2} \mathrm{~S}$ exposure might simply reflect tissue damage and onset of death. Although no mortality was observed during the exposure period it was noted that 5 specimens left in the set-up were all dead after $780 \mathrm{~min}$.

In order for $\mathrm{H}_{2} \mathrm{~S}$ entering Saduria entomon via the gills to be detoxified, it must be transported to the hepatopancreas. Since $\mathrm{H}_{2} \mathrm{~S}$ enters directly into the blood, which is in circulatory connection with the hepatopancreas (Gibson \& Barker 1979), the blood seems to mediate this transport. In Bythograea thermydron, Childress et al. (1987) found $\mathrm{H}_{2} \mathrm{~S}$ to be transported in a free form in the blood (i.e. no interaction with hemocyanin or special transport proteins). The blood of $B$. thermydron does not exhibit sulfide oxidation activity (Vetter et al. 1987), as is also the case for $S$. entomon. The lack of sulfide oxidation activity in crustacean blood supports the hypothesis that $\mathrm{H}_{2} \mathrm{~S}$ is transported in a free form. In other words, hemocyanin seems different from, e.g. hemoglobin, methemoglobin, or hematin, which have all been shown to react with $\mathrm{H}_{2} \mathrm{~S}$ (Baxter \& VanReen 1958b, Sörbo 1958, Patel \& Spencer 1963, Smith \& Gosselin 1966, Powell \& Arp 1989). The $\mathrm{O}_{2}$-transport by hemocyanin can therefore proceed in the presence of $\mathrm{H}_{2} \mathrm{~S}$. This is further supported by the $\mathrm{O}_{2}$-dependent production of $\mathrm{SO}_{3}{ }^{2-}$ and $\mathrm{S}_{2} \mathrm{O}_{3}{ }^{2-}$ in the hepatopancreas of $S$. entomon. 
The final step in the transport of $\mathrm{H}_{2} \mathrm{~S}$ by blood is diffusion of $\mathrm{H}_{2} \mathrm{~S}$ from the blood into the hepatopancreas. A passive net transport out of the animal into the fluid component of the hepatopancreas only occurs when the $\mathrm{H}_{2} \mathrm{~S}$ concentration is higher in the blood. However, the in vivo experiments all showed $\mathrm{H}_{2} \mathrm{~S}$ concentration to be higher in the hepatopancreas of Saduria entomon. Although not recognized, this enigma can also be seen in other studies (e.g. Childress et al. 1984, Bagarinao \& Vetter 1989). However, the acid labile bound $\mathrm{H}_{2} \mathrm{~S}$ in the hepatopancreas of $S$. entomon might be an explanation. Since $S$. entomon cannot exclude $\mathrm{H}_{2} \mathrm{~S}$, the fact that $\mathrm{H}_{2} \mathrm{~S}$ concentration in blood was lower than that in water shows that $\mathrm{H}_{2} \mathrm{~S}$ is transported via blood to hepatopancreas. In Riftia pachyptila, Childress et al. (1984) ascribed the apparent concentration of $\mathrm{H}_{2} \mathrm{~S}$ in the trophosome to be an overestimate, due to the presence of acid labile $\mathrm{H}_{2} \mathrm{~S}$ characteristic of bacterial ferrodoxins.

In conclusion, the present study adds new evidence for the hypothesis that physiological adaptations to $\mathrm{H}_{2} \mathrm{~S}$ are not unique to animals from the hydrothermal vents. Adaptations to $\mathrm{H}_{2} \mathrm{~S}$ allow numerous species to extend their ecological niche; this makes $\mathrm{H}_{2} \mathrm{~S}$ an important factor in the distribution of marine invertebrates in soft sediments. In Saduria entomon, adaptations to low $\mathrm{p}_{\mathrm{w}} \mathrm{O}_{2}$ and $\mathrm{H}_{2} \mathrm{~S}$ can explain the species' present distribution in the Baltic Sea.

Acknowledgements. I thank Prof. Tom Fenchel and Dr Lars Hagerman for discussions and suggestions on the manuscript. I am indebted to Dr Paul R. Dando for advice on HPLC techniques. This study was supported by Danish Natural Science Research Council grant no. 11-6737. University of Copenhagen grant no. 001-2,3-199 and the Commission of European Communities (MAST contract no. 0044).

\section{LITERATURE CITED}

Anderson, A. E., Childress, J. J., Favuzzi, J. A. (1987). Net uptake of $\mathrm{CO}_{2}$ driven by sulphide and thiosulphate oxidation in the bacterial symbiont-containing clam Solemya reidi. J. exp. Biol. 133: 1-31

Bagarinao, T., Vetter, R. D. (1989). Sulfide tolerance and detoxification in shallow-water fishes. Mar Biol. 103: 291-302

Bagarinao, T. Vetter, R. D. (1990). Oxidative detoxification of sulfide by mitochondria of the California killifish Fundulus parvipinnis and the speckled sanddab Citharichthys stigmaeus. J. comp. Physiol. (Sect. B) 160: 519-527

Barker, P. L., Gibson, R. (1977). Observations on the feeding mechanism, structure of the gut, and digestive physiology of the european lobster Homarus gammarus (L.) (Decapoda: Nephropidae). J. exp. mar. Bjol. Ecol. 26: $297-324$

Baxter, C. F., VanReen, R. (1958a). Some aspects of sulfide oxidation by rat-liver preparations. Biochim. biophys. Acta 28: $567-573$

Baxter, C. F., VanReen, R. (1958b). The oxidation of sulfide to thiosulfate by metallo-protein complexes and by ferritin. Biochim. biophys. Acta 28: 573-578

Baxter, C. F., VanReen, R., Pearson, P. B., Rosenberg, C (1958). Sulfide oxidation in rat tissues. Biochim. biophys. Acta $27 \cdot 584-591$

Buchanan, J. B., Brown, B. E., Coombs, T. L., Pirie, B. J. S., Allen, J. A. (1980). The accumulation of ferric iron in the guts of some spatangoid echinoderms. J. mar. biol. Ass. U.K. 60: 631-640

Childress, J. J., Arp, A. J., Fisher, C. R. (1984). Metabolic and blood characteristics of the hydrothermal vent tube-worm Riftia pachyptila. Mar. Biol. 83: 109-124

Childress, J. J., Felbeck, H., Somero, G. N. (1987). Symbiosis in the deep sea. Scient. Am. 256(5): 106-112

Curtis, C. G., Bartholomew, T. C., Rose, F. A., Dodgson, K. S. (1972). Detoxication of sodium ${ }^{35} \mathrm{~S}$-sulphide in the rat. Biochem. Pharmac. 21: 2313-2321

De Ridder, C., Jangoux, M., De Vos, L. (1985). Description and significance of a peculiar intradigestive symbiosis between bacteria and a deposit-feeding echinoid. J. exp. mar. Biol. Ecol. 91: 65-76

Degn, H., Kristensen, B. (1981). Low sensitivity of Tubifex sp. respiration to hydrogen sulfide and other inhibitors. Comp. Biochem. Physiol. 698: 809-817

Dziewiatkowski, D. D. (1945). Fate of ingested sulfide sulfur labeled with radioactive sulfur in the rat. J. biol. Chem. 161: 723-729

Evans, C. L. (1967). The toxicity of hydrogen sulphide and other sulphides. Quart. J. exp. Physiol. 52: 231-248

Fahey, R. C., Newton, G. L. (1987). Determination of lowmolecular-weight thiols using monobromobimane fluorescent labeling and high-performance liquid chromatography. Meth. Enzym. 143: 85-97

Fenchel, T (1969). The ecology of marine microbenthos IV Structure and function of the benthic ecosystem, its chemical and physical factors and the microfauna communities with special reference to the ciliated protozoa. Ophelia 6 : $1-182$

Fenchel, T M., Riedl, R. J. (1970). The sulfide system: a new biotic community underneath the oxidized layer of marine sand bottoms. Mar. Biol. 7: 255-268

Gibson, R., Barker, P. L. (1979). The decapod hepatopancreas. Oceanogr. mar. Biol. A. Rev. 17·285-346

Haathela, I. (1962). Kilkin biologiasta ja pyydystämisestä. Suom. Kalastuslehti 69: 9-15 (in Finnish)

Hagerman, L., Szaniawska, A. (1988). Respiration, ventilation and circulation under hypoxia in the glacial relict Saduria (Mesidotea) entomon. Mar Ecol. Prog. Ser. 47: 55-63

Hagerman, L., Szaniawska, A. (1990). Anaerobic metabolic strategy of the glacial relict isopod Saduria (Mesidotea) entomon. Mar. Ecol. Prog. Ser. 59: 91-96

Haggard, H. W. (1921). The fate of sulfides in the blood. J. biol. Chem. 49: 519

Hand, C. H., Somero, G. N. (1983). Energy metabolism pathways of hydrothermal vent animals: adaptations to a foodrich and sulfide-rich deep-sea environment. Biol. Bull. mar biol. Lab., Woods Hole 165: 167-181

Holmes, W. N., Donaldson, E. M. (1969). The body composition and distribution of electrolytes. In: Hoar, W S., Randall, D. J. (eds.) Fish physiology, Vol. 1 Academic Press. New York, p. 1-227

Jacubowa, L., Malm, E. (1931). Die Beziehungen einiger Benthos-Formen des Schwarzen Meeres zum Medium. Biol. Zbl. 51. 105-116

Jaeschke, H. (1990). Glutathione disulfide as index of oxidant stress in rat liver during hypoxia. Am. J. Physiol. 258(4): G499-G505 
Koj, A. (1968). Enzymic reduction of thiosulphate in preparations from beef liver. Acta biochim. pol. 15: 161-169

Koj, A., Frendo, J. (1967). Oxidation of thiosulphate to sulphate in animal tissues. Folia Biol. (Krakow) 15:49-63

Kosower, N. S., Kosower, E. M. (1983). Glutathione and cell membrane thiol status. In: Larsson, A et al. (eds.) Functions of glutathione: biochemical, physiological, toxicological, and clinical aspects. Raven Press, New York, p. $307-315$

Lauren, D. R., Watkinson, J. H. (1985). Elemental sulphur analysis using high-performance liquid chromatography on 10- $\mu \mathrm{m}$ rigid polymer particles. J. Chromat. 348: 317-320

Lucu, C. (1990). Ionic regulatory mechanisms in crustacean gill epithelia. Comp. Biochem. Physiol. 97A(3): 297-306

Meister, A. (1975). Biochemistry of glutathione. In: Greenberg, D. M. (ed.) Metabolic pathways, Vol. 3, Metabolism of sulfur compounds, 3rd edn. Academic Press, New York, p. $101-188$

Meister, A. (1983). Metabolism and transport of glutathione and other $\gamma$-glutamyl compounds. In: Larsson, A. et al. (eds.). Functions of glutathione: biochemical, physiological, toxicological, and clinical aspects. Raven Press, New York, p. 1-22.

Meyers, M. B., Fossing, H., Powell, E. N. (1987). Microdistribution of interstitial meiofauna, oxygen and sulfide gradients, and the tubes of macro-infauna. Mar. Ecol. Prog Ser. 35: 223-241

Meyers, M. B., Powell, E. N., Fossing, H. (1988). Movement of oxybiotic and thiobiotic meiofauna in response to changes in pore-water oxygen and sulfide gradients around macroinfaunal tubes. Mar Biol. 98: 395-414

Moriarty, D. J. W., Nicholas, D. J. D. (1969). Enzymic sulphide oxidation by Thiobacillus concretivorus. Biochim. biophys Acta 184: 114-123

National Research Council (Division of Medical science, Subcommittee on Hydrogen sulfide) (1979). Hydrogen sulfide. University Press, Baltimore

O'Brien, J., Vetter, R. D. (1990). Production of thiosulphate during sulphide oxidation by mitochondria of the symbiont-containing bivalve Solemya reidi. J. exp. Biol. 149: $133-148$

Oertzen, J.-A. von, Schlungbaum, G. (1972). Experimentellökologische Untersuchungen über $\mathrm{O}_{2}$-Mangel- und $\mathrm{H}_{2} \mathrm{~S}$ Resistenz an marinen Evertebraten der westlichen Ostsee Beitr. Meeresk. 29: 79-91

Oeschger, R, Janssen, H. H. (1991). Histological studies on Halicruptus spinulosus (Priapulida) with regard to environmental hydrogen sulfide resistance. Hydrobiologia (in press)

Oeschger, R., Schmaljohann, R. (1988). Association of various types of epibacteria with Halicryptus spinulosus (Priapulidal. Mar. Ecol. Prog. Ser. 48: 285-293

Oeschger, R., Storey, K. B. (1990). Regulation of glycolytic enzymes in marine invertebrate Halicryptus spinulosus (Priapulida) during environmental anoxia and exposure to hydrogen sulfide. Mar. Biol. 106: 261-266

Patel, S., Spencer, C. P. (1963). The oxidation of sulphide by the haem compounds from the blood of Arenicola marina. J. mar. biol. Ass. U.K. 43: 167-175

This article was submitted to the editor
Powell, E. N., Crenshaw, M. A., Rieger, R. M. (1979). Adaptations to sulfide in the meiofauna of the sulfide system. I ${ }^{35} \mathrm{~S}$-sulfide accumulation and the presence of a sulfide detoxification system. J. exp. mar Biol. Ecol. 37. 57-76

Powell, E. N., Crenshaw, M. A., Rieger, R. M. (1980). Adaptations to sulfide in sulfide-system meiofauna. Endproducts of sulfide detoxification in three turbellarians and a gastrotrich. Mar. Ecol. Prog. Ser. 2: 169-177

Powell, M. A., Arp, A. J. (1989). Hydrogen sulfide oxidation by abundant nonhemoglobin heme compounds in marine invertebrates from sulfide-rich habitats. $J$. exp. Zool. 249: $121-132$

Powell, M. A., Somero, G. N. (1985). Sulfide oxidation occurs in the animal tissue of the gutless clam, Solemya reidi. Biol Bull mar. biol. Lab., Woods Hole 169: 164-181

Powell, M. A., Somero, G. N. (1986). Hydrogen sulfide oxidation is coupled to oxidative phosphorylation in mitochondria of Solemya reidi. Science 233: 563-566

Siegel, L. M. (1975). Oxidation of reduced sulfur compounds in animals. In: Greenberg. D. M. (ed.) Metabolic pathways, Vol.3, Metabolism of sulfur compounds, 3rd edn. Academic Press, New York, p. 275-286

Smith, R. P., Abbanat, R. A. (1966). Protective effect of oxidized glutathione in acute sulfide poisoning. Toxic. appl. Pharmac. 9: 209-217

Smith, R. P., Gosselin, R. E. (1966). On the mechanism of sulfide inactivation by methemoglobin. Toxic. appl. Pharmac. 8: 159-172

Sörbo, B. (1958). On the formation of thiosulfate from inorganic sulfide by liver and heme compounds. Biochim. biophys. Acta 27: 324-329

Sörbo, B. (1960). On the mechanism of sulfide oxidation in biological systems. Biochim. biophys. Acta 38: 349-351

Sorbo, B. (1964). Mechanism of oxidation of inorganic thiosulfate and thiosulfate esters in mammals. Acta chem. scand. 18: 821-823

Theede, H., Ponat, A., Hiroki, K., Schlieper, C. (1969). Studies on the resistance of marine bottom invertebrates to oxygen deficiency and hydrogen sulphide. Mar. Biol. 2: 325-337

Vargo, S. L., Sastry, A. N. (1978). Interspecific differences in tolerance of Eurytemora affinis and Acartia tonsa from an estuarine anoxic basin to low dissolved oxygen and hydrogen sulfide. In: McLusky, D. S., Berry, A. J. (eds.) Physiology and behavior of marine organisms. Pergamon Press, Oxford, p. 219-226

Vetter, R. D., Matrai, P. A., Javor, B., O'Brien, J. (1989) Reduced sulfur compounds in the marine environment: analysis by high-performance liquid chromatography Symp. Ser. Am. chem. Soc. 393: 243-261

Vetter, R. D., Wells, M. E., Kurtsman, A. L., Somero, G. N. (1987). Sulfide detoxification by the hydrothermal vent crab Bythograea thermydron and other decapod crustaceans. Physiol. Zool. 60(1): 121-137

Vismann, B. (1990). Sulfide detoxification and tolerance in Nereis (Hediste) diversicolor and Nereis (Neanthes) virens (Annelida: Polychaeta). Mar. Ecol. Prog. Ser 59: 229-238

Yokoyama, E., Yoder, R. E., Frank, N. R. (1971). Distribution of ${ }^{35} \mathrm{~S}$ in blood and its excretion in urine of dogs exposed to ${ }^{35} \mathrm{SO}_{2}$. Archs envir. Hlth 22: 389-395

Manuscript first received: January 29, 1991

Revised version accepted: August 12, 1991 